such unfair competition actions, then the federal court should not be excused from doing the same.

Third, the area of unfair competition is said to be peculiarly appropriate for national regulation and therefore state law should not be applied to a pendent claim. It appears that this consideration is simply an argument for creation of federal rights concerning unfair competition, in which case a claim solely for unfair competition would be a basis for federal jurisdiction. So long as Congress has not chosen to make unfair competition a federal question, ${ }^{43}$ the federal judiciary should not on its own initiative attempt such trade regulation.

Even if these "practical" considerations are to be given unjustified weight, the doctrine of the Erie case would appear to require application of state law to pendent claims. In any event, these considerations would not apply to pendent claims not involving unfair competition. Furthermore, if the Supreme Court is prepared to follow the contention of Justice Brandeis that the Erie rule is a constitutional requirement, ${ }^{44}$ then the repeated application of federal precedents to pendent claims stands condemned by the Constitution.

${ }^{2}$ Consult note 27 supra.

« Consult note 39 supra.

\title{
NOTICE BY PUBLICATION: WALKER $V$. CITY OF HUTCHINSON
}

"It is common knowledge that mere newspaper publication rarely informs a landowner of proceedings against his property." "Stamping this common knowledge with the imprimatur of due process, the Supreme Court in Walker v. City of Hutchinson ${ }^{2}$ held invalid a condemnation proceeding based on notice by publication. Though the Court's decision brings this area of the law into pace with the times, its extension of Mullane v. Central Hanover Trust $\mathrm{Co}^{3}$ creates a host of problems involving the validity of concluded proceedings.

The Mullane case, ${ }^{4}$ a landmark decision defining a new approach to the due process requirement of notice, was a proceeding by a trustee for a settlement and accounting of a common trust fund established under a New York statute. Notice had been published weekly for four successive weeks in a newspaper of general circulation as required by the statute. On appeal from

${ }^{1}$ Walker v. City of Hutchinson, 352 U.S. 112, 116 (1956).

${ }^{2}$ Ibid.

333 U.S. 306 (1950).

'Ibid. The case caused a good deal of comment. Consult, e.g., Perry, The Mullane Doctrine-A Reappraisal of Statutory Notice Requirements, Current Trends in State Legislation 33 (1952); Fraser, Jurisdiction by Necessity-An Analysis of the Mullane Case, 100 U. of Pa. L. Rev. 305 (1951). 
a finding that such notice was sufficient, ${ }^{5}$ it was held that as to beneficiaries, resident and non-resident, whose place of residence was known or could have been ascertained with reasonable diligence such notice was insufficient under the Fourteenth Amendment.

The statutory notice to known beneficiaries is inadequate, not because in fact it fails to reach everyone, but because under the circumstances it is not reasonably calculated to reach those who could easily be informed by other means at hand. ${ }^{\circ}$

Since the trustee's proceeding for settlement and accounting is of a special nature and cannot clearly be termed in rem, quasi in rem, or in personam, ${ }^{7}$ categories into which the bulk of litigation is classified, the extent of application of the Mullane decision was not clear. The New York reaction was only to amend its statute governing these proceedings; ${ }^{8}$ state courts generally have construed the decision narrowly. ${ }^{9}$

5 In re Central Hanover Bank \& Trust Co., 299 N.Y. 697, 87 N.E.2d 73 (1949).

${ }^{\circ}$ Mullane v. Central Hanover Trust Co., 339 U.S. 306, 319 (1950).

'See ibid., at 312 .

${ }^{8}$ N.Y. Laws (1951) c. $778, \$ 3$. Some states interpreted the decision in a broader manner. Consult Mullane v. Central Hanover Bank and Trust Co.-Statutory Reaction, 30 Iowa L. Rev. 665 (1954).

${ }^{9}$ In re Shew's Estate, 48 Wash.2d 732, 296 P.2d 667 (1956) (distinguished Mullane as being in personam while this action was in rem); In re Pierce's Estate, 245 Iowa 22, 60 N.W.2d 894 (1953) (distinguished on ground that admitting will to probate was not as final as action in Mullane-also, rights of objectors, in this case, were contingent upon successful contest of the will) ; State v. American-Hawaiian S. S. Co., 29 N.J.Super. 116, 101 A.2d 598 (1953) (held Mullane did not apply to statute providing for protective custody); Wisconsin Electric Power Co. v. Milwaukee, 263 Wis. 111, 56 N.W.2d 784 (1953) (no reason given); New York Merchandise Co. v. Stout, 43 Wash.2d 825, 264 P.2d 863 (1953) (Mullane confined to its facts) ; Devitt v. Milwaukee, 261 Wis. 276, 52 N.W.2d 872 (1952) (distinguished as involving governmental power); Gazan v. Corbett, 278 App.Div. 953, 105 N.Y.S.2d 187 (2d Dep't, 1951) (no reason given) ; Newark v. Yeskel, 5 N.J. 313, 74 A.2d 883 (1950) (distinguished as involving governmental power).

One author has maintained that there were no prior holdings contrary to the Mullane decision. Perry, The Mullane Doctrine-A Reappraisal of Statutory Notice Requirements, Current Trends in State Legislation 33, 43-72 (1952). He distinguishes all Supreme Court cases supporting notice by publication where the defendant's name and address might have been known on the ground that the plaintiff was a governmental agency exercising its sovereign power. He construes Arndt v. Griggs, 134 U.S. 316 (1890), a suit concerning an action to quiet title by a purchaser at a tax sale, as a case involving "governmental power," since, although the action was brought by the purchaser of the land, "it was an established part of the procedure for sale for delinquent taxes, and was so recognized by the Court." Ibid., at $71 \mathrm{n} .161$. It is interesting to note that state courts in circumventing the Mullane case have taken advantage of this point. "The difference between a proceeding for the settlement of a trust account by a banking institution and a proceeding by a political subdivision of the state to enforce the payment of taxes which have been regularly assessed and levied is patent." Devitt v. Milwaukee, 261 Wis. 276, 283, 52 N.W.2d 872, 875 (1952), quoting from Newark v. Yeskel, 5 N.J. 313, 321, 74 A.2d 883, 887 (1950). The Walker case has done away with this distinction. "There is nothing peculiar about litigation between the government and its citizens that should deprive those citizens of a right to be heard." Walker v. City of Hutchinson, 352 U.S. 112, 117 (1956).

Perry, op. cit. supra, at 37 , has also suggested that the Mullane case might be construed as simply holding that where a custodian in charge of property proceeds against a known 
Walker v. City of Hutchinson, ${ }^{10}$ decided during the present term, indicates that the New York legislature and the state courts failed to recognize the full implication of the Mullane decision. ${ }^{11}$ The plaintiff, a resident Kansas landowner, sued to enjoin the city from entering upon his property which had been condemned under a Kansas statute. ${ }^{12} \mathrm{He}$ contended that the newspaper publication, though adequate notice under the statute regarding proceedings to fix compensation, ${ }^{13}$ was insufficient notice to meet the standards of the Fourteenth Amendment. The Kansas Supreme Court affirmed a judgment for the city, ${ }^{14}$ but on appeal to the United States Supreme Court it was held, with two justices dissenting, ${ }^{15}$ that where the landowner's name and address were known, newspaper publication alone was not sufficient. ${ }^{10}$ Huling $v$. Karv Valley $R y$. Co., ${ }^{17}$ a case otherwise directly in point, ${ }^{18}$ was distinguished on the sole ground that the landowner was a non-resident. But by the Court's own analysis such a distinction is unsupportable ${ }^{19}$ since the Court's decision was

owner he must give him better notice than mere publication. The validity of this position is doubtful. The duties of a custodian are a question of state law. Since the Supreme Court will not reverse the highest state court on such a matter, its reversal in the Mullane case can hardly be explained in terms of a special obligation imposed upon caretakers.

${ }^{10} 352$ U.S. 112 (1956).

${ }^{11}$ In City of New York v. New York, N. H. \& H. R. Co., 344 U.S. 293 (1953), the Court indicated that the doctrine of the Mullane case might not be confined to its particular facts. In a proceeding under the Bankruptcy Act for the reorganization of a railroad the district court required notice to be mailed to the mortgage trustees and all creditors who had already appeared in court; all others had to depend for notice on two publications in five daily newspapers. New York City did not file its claims within the required time and the court enjoined the enforcement of its liens. On appeal the Supreme Court held that the notice provided by the court was not adequate under the circumstances. Since there was no discussion of the Fifth Amendment, however, the Court's reasoning appears to have been that the notice given did not conform to that required by the statute.

${ }^{12}$ G.S. Kan. (1949) $\$ 26-201$, quoted in Walker v. City of Futchinson, 352 U.S. 112, 113 (1956).

${ }^{13}$ G.S. Kan. (1949) $\$ 26-202$, quoted in the Court's opinion ibid., at 113-14.

14 Walker v. City of Hutchinson, 178 Kan. 263, 284 P.2d 1073 (1955). The court did not discuss or cite the Mullane case.

${ }^{15}$ Justice Frankfurter and Justice Burton. Justice Burton was the sole dissenter in the Mullane case.

${ }^{10}$ In considering the Court's holding in the Walker case it is worthy of note that the case might have been decided on narrower grounds, only one publication was made (Brief for Appellant, at 12-14).

${ }^{17} 130$ U.S. 559 (1889).

${ }^{18}$ The Huling case, ibid., like others upholding notice by publication, does not state the facts in sufficient detail to determine whether or not the interested party's name and address were known. However, its language, also like the others, appears broad enough to cover this situation.

${ }^{10}$ The Court's opinion reflects a recognition of the weakness of this distinction: "Since appellant in this case is a resident of Kansas, we are not called upon to consider the extent to which Mullane may have undermined the reason of the Huling decision." Walker v. City of Hutchinson, 352 U.S. 112, 116 (1956). 
dictated by standards of fairness inherent in the concept of notice-standards which appear hardly less applicable to non-residents than to residents. ${ }^{20}$

The Walker and Mullane decisions establish that publication is an insufficient means of notifying a party of his interest in pending litigation when his name and address are known. ${ }^{21}$ These decisions reflect the Court's recognition that the mails, though they may once have been an unreliable mode of communication, have become a dependable means of giving notice, ${ }^{22}$ and that newspaper publication, though it may once have been acceptable, has lost its efficacy. ${ }^{23}$

In elevating the standards of acceptable notice the Court in the Walker case did what the Mullane decision failed to do-discredit the "caretaker" theory upon which the cases upholding notice by publication had relied. ${ }^{24}$ According to this theory a property owner is deemed to have someone in charge of his property who will give him notice of any legal action affecting his interest. Since the Court has relied upon this theory in cases involving no physical interference with the property calculated to attract the attention of a caretaker, ${ }^{25}$ the theory seems to have rested on the assumption that the caretaker would discover and inform the owner of all published notices relating to his property. When the Supreme Court held notice by publication insufficient to inform the owner in the Walker case, it seems to have discarded this assumption.

${ }^{20}$ While the difference between resident and non-resident may be of controlling significance on the question of jurisdiction over the person of the defendant, it is difficult to imagine how this difference could affect standards of adequate notice. The courts appear occasionally to have confused these separate jurisdictional prerequisites, perhaps because in a typical in personam action notice is given by personal service, the same act which secures jurisdiction.

${ }^{21}$ The problem of determining when the name and address of an interested party are "known" complicates the application of these decisions. There are no difficulties in regard to recorded interests, but questions of good faith arise in cases typified by an ex parte divorce suit. The complainant is the person most likely to know the spouse's address and yet it may be advantageous to keep it a secret.

Both Mullane and Walker approve a line of cases which uphold published notice where the defendant's name and address are unknown. Standard Oil Co. v. New Jersey, 341 U.S. 428 (1951); Anderson Nat'l Bank v. Luckett, 321 U.S. 233 (1944); Security Savings Bank v. California, 263 U.S. 282 (1923); Jacobs v. Roberts, 223 U.S. 261 (1912).

23 "However it may have been in former times, the mails today are recognized as an efficient and inexpensive means of communication." Mullane v. Central Hanover Trust Co., 339 U.S. 306, 319 (1950).

${ }^{23}$ See the statement of the Court in Walker v. City of Hutchinson, quoted in text at note 1 supra.

${ }^{2}$ North Laramie Land Co. v. Hoffman, 268 U.S. 276 (1925); Hulling v. Kaw Valley Ry. Co., 130 U.S. 559 (1889). See Mullane v. Central Hanover Trust Co., 339 U.S. 306, 316 (1950); Pennoyer v. Neff, 95 U.S. 714, 727 (1878).

$\approx$ North Laramie Land Co. v. Hoffman, 268 U.S. 276 (1925) ; Huling v. Kaw Valley Ry. Co., 130 U.S. 559 (1889). Nor did the statutes involved in these cases require any such action. 
Nor is it likely that the "caretaker" notion retains any usefulness as a rationale for holding published notice adequate when coupled with official intereference with the property (such as physical seizure or posting). In support of such a position it would be argued, by analogy to the garnishment proceeding where no formal notice to the real party in interest is required, ${ }^{20}$ that such interference would warn the caretaker and be transmitted to the owner. The circumstances are not analogous, however, since the caretaker is usually fictional, and even a real caretaker would lack the incentive to notify that the penalty for failing to act gives the garnishee. ${ }^{27}$

The most serious problem created by the Walker case arises not from future controversies, ${ }^{28}$ but from proceedings already "concluded." As indicated in Justice Burton's dissenting opinion, ${ }^{29}$ the courts are now faced with the problem of collateral attack on prior default judgments by a party who contends that although his name and address were known or could reasonably have been ascertained he was denied due process in a judicial proceeding concerning which the statute required only notice by publication. If the plaintiff did not appear at the proceeding being attacked, ${ }^{30}$ it would seem that he has

${ }^{3}$ See Harris v. Balk, 198 U.S. 215, 228 (1905).

27 "[T] he failure on the part of the garnishee to give proper notice to his creditor of the levying of the attachment would be such a neglect of duty on the part of the garnishee which he owed to his creditor as would prevent his availing himself of the judgment in the attachment suit as a bar to the suit of his creditor against himself, which might therefore result in his being called upon to pay the debt twice." Ibid., at 228 .

The overthrow of the rule set out in Harris v. Balk, sanctioning notice by the garnishee as adequate to inform the debtor, is not unforeseeable. Notice to the debtor in these proceedings is susceptible to false proof of notice by a person who is motivated in that direction (i.e., a garnishee who has neglected to give actual notice). Cf. Wuchter v. Pizzutti, 276 U.S. 13 (1928), discussed in note 30 infra.

${ }^{28}$ At the time of the Mullane decision thirty-four jurisdictions had statutes in effect requiring more than mere notice by publication where the parties were known. Hayward, The Effect of Mullane v. Central Hanover Bank and Trust Company Upon Publication of Notice in Iowa, 36 Iowa L. Rev. 47, 57-58 (1950). Two state legislatures changed their requirements as a direct result of that case. Mullane v. Central Hanover Bank and Trust Co.-Statutory Reaction, 39 Iowa L. Rev. 665 (1954). It is probable that many of the remaining fifteen will react similarly to the Walker case.

"Particularly, I am not ready to throw a nationwide cloud of uncertainty upon the validity of condemnation proceedings based on compliance with similar local statutes." Walker v. City of Hutchinson, 352 U.S. 112, 127 (1956).

${ }^{30}$ If the defendant had appeared and defended in the original proceeding, he should not be allowed to attack the judgment collaterally. A party should not be allowed to attack for lack of notice a judgment rendered in a proceeding to which he was a party. Cf. Tyler v. Judges of Court of Registration, 179 U.S. 405 (1900). Wuchter v. Pizzutti, 276 U.S. 13 (1928), is not contrary in holding that actual notice was inadequate to support a default judgment where the statute did not require constitutionally acceptable notice. If the default judgment in that case had been allowed to stand, defendants would have been subjected to all the dangers of false proof of actual notice, a danger not present when the defendant has actually appeared. 
a prima facie case, since the Supreme Court has held that actual notice will not save an inadequate statute. ${ }^{31}$

While a state court has the power to apply its own decision retrospectively ${ }^{32}$ or prospectively only, ${ }^{33}$ it is not clear whether or not it may limit a decision of the Supreme Court to prospective application. The United States Supreme Court had formerly expressed its acceptance of the declaratory theory of law, ${ }^{34}$ the position that a judicial opinion is merely an indication of the law and not law itself so that when a decision is overruled it does not become bad law but simply was never law at all. If the Court were to adhere to that theory in a situation such as that in the Walker case or in any of the other in rem or quasi in rem proceedings where statutes have allowed notice by publication, ${ }^{35}$ it would appear that all prior default judgments obtained under such statutes could be reopened. The problems thus raised are readily apparent.

More recently, in recognition of these difficulties, the Court has indicated its dissatisfaction with this unrealistic position:

The courts below have proceeded on the theory that the Act of Congress, having been found to be unconstitutional, was not a law; that it was inoperative, conferring no rights and imposing no duties, and hence affording no basis for the challenged decree.... It is quite clear, however, that such broad statements as to the effect of a determination of unconstitutionality must be taken with qualifications. The actual existence of a statute, prior to such a determination, is an operative fact and may have consequences which cannot justly be ignored. The past cannot always be erased by a new judicial declaration. The effect of the subsequent ruling as to invalidity may have to be considered in various aspects, - with respect to particular relations, individual and corporate, and particular conduct, private and official. Questions of rights claimed to have been vested, of status, of prior determinations deemed to

${ }^{31}$ Wuchter v. Pizzutti, 276 U.S. 13 (1928).

${ }^{32}$ The constitutionality of such action appears to have withstood three distinct attacks. The Supreme Court has held that Article 1, Section 10, prohibiting states from passing ex post facto laws, refers only to legislative action. Frank v. Magnum, 237 U.S. 309 (1915). Article 1, Section 10, prohibiting states from passing laws impairing contracts, also refers only to legislation. Tidal Oil Co. v. Flanagan, 263 U.S. 444 (1924) ; Central Land Co. v. Laidley, 159 U.S. 103 (1895). And such retrospective application does not violate the Due Process Clause of the Fourteenth Amendment. Tidal Oil Co. v. Flanagan, supra; Central Land Co. v. Laidley, supra.

${ }^{3}$ Consult discussion at 559 infra. Decisions involving prospective application are cited in Snyder, Retrospective Operation of Overruling Decisions, 35 Il. L. Rev. 121 (1940) ; Prospective Operation of Decisions Holding Statutes Unconstitutional or Overruling Prior Decisions, 60 Harv. L. Rev. 437 (1947).

${ }^{34}$ Norton v. Shelby County, 118 U.S. 425 (1886).

${ }^{25}$ E.g., adoption, N.C. Stat. Ann. (1953) $\$ 1-98(10)$; attachment, Kan. Stat. Ann. (1949) $\$ 61-408$; divorce, Iowa Rules Civ. Proc. (1950) 60(i); mortgage foreclosure, N.H. Stat. Ann. (1955) \$479:19; partition, Ind. Stat. Ann. (Burns, 1946) $\$ 2-807(6)$; probate, Neb. Stat. Ann. (1948) \$25-517; quiet title, Neb. Stat. Ann. (1948) \$25-517; sale of land for delinquent taxes, Ark. Stat. Ann. (1947) \$84-1103. 
have finality and acted upon accordingly, of public policy in the light of the nature both of the statute and of its previous application, demand examination. ${ }^{36}$

In Great Nothern Ry. v. Sunburst Oil \& Refining Co., ${ }^{3 \pi}$ a review of a state supreme court decision overruling prior authority, it was contended that the exclusively prospective application of the new decision-that is, disposition of the case at bar on the basis of the overruled authority-was a denial of due process. The Supreme Court held that the federal Constitution had no application. ${ }^{38}$ But to say that a state can limit its own overruling decisions to prospective application is not clearly to say that it can do the same with a decision of the United States Supreme Court. ${ }^{39}$ The power of a state court to limit such decisions to prospective application, as well as the appropriateness of that limitation under any given circumstance, are questions ultimately reviewable by the United States Supreme Court. Up to the present time, however, the Court has never held that a state court could not make such a limitation.

It is also unclear whether or not a state legislature may act to prevent or limit the reopening of these prior proceedings. It is well established that a state may pass a statute limiting the time within which actions can be brought, so long as it allows a reasonable time for the assertion of existing claims. ${ }^{40}$ Thus, a state might adopt a statute providing that all prior judgments based upon notice by publication were valid unless contested within one year from the date of the enactment. ${ }^{41}$ But if a party has never had notice of proceedings against property which he owns or has claims against, ${ }^{42}$ there are difficulties

${ }^{36}$ Chicot County Drainage District v. Baxter State Bank, 308 U.S. 371,374 (1940). See Addison v. Holly Hill Co., 322 U.S. 607, 619-22 (1944). Consult the concurring opinion of Frankfurter, J., in Griffin v. Illinois, 351 U.S. 12, 25-26 (1956) (urging prospective application of Court's decision, summarized in note 39 infra).

${ }^{37} 287$ U.S. 358 (1932).

38 "A state in defining the limits of adherence to precedent may make a choice for itself between the principle of forward operation and that of relation backward. It may say that decisions of its highest court, though later overruled, are law nonetheless for intermediate transactions. ... [T] [Te choice for any state may be determined by the juristic philosophy of the judges of her courts, their conception of law, its origin and nature." Tbid., at 364-65.

${ }^{30}$ As a result of Griffin v. Illinois, 351 U.S. 12 (1956) (state must provide indigent prisoners with trial transcripts for purposes of appellate review), the Hlinois Supreme Court promulgated Rule 65-1 providing that all indigent prisoners incarcerated before the Griffin decision may also obtain such transcripts. The court may have felt either that it did not have the power to limit the Griffin decision to prospective application or that fairness required retroactivity.

${ }^{10}$ Atchafalaya Co. v. Williams Cypress Co., 258 U.S. 190 (1922); Turner v. New York, 168 U.S. 90 (1897); Wheeler v. Jackson, 137 U.S. 245 (1890).

${ }^{41}$ Consult Iowa Laws (1951) c. 210 and Wis. Statutes (1955) $§ 330.52$.

$\triangle$ Although there might be situations where the defendant would have actual notice of an existing claim, making the situation analogous to that under the ordinary statutes of limitation, this will not always be the case. It is quite probable that a landowner will have 
in putting him in the same class with parties who are barred by laches. Since a party may be barred by adverse possession without actual notice of an infringement of his rights, ${ }^{43}$ the statute might better be cast as a general, rather than a remedial, statute of limitation. Such a law would render incontestable rights held under color of a judgment for over $\mathrm{X}$ years. In any event, either suggested legislative solution would not deal with the problem of those plaintiffs who file their actions in time.

Another possible remedy would be a statute raising a presumption in favor of the findings on the merits in the proceeding attacked. Thus, a party seeking to overturn a judgment under an attachment statute would have to show not only an absence of due process but also some error in the decision on the merits in the prior case: for example, that he did not owe the debt for which the attachment and sale were obtained. But if all that the law requires a landowner to show to recover his land is that the attachment judgment was void, ${ }^{44}$ a statute giving a measure of validity to this void decree by raising a presumption in favor of its findings might well be unconstitutional. Even if it were constitutional, such a statute would still leave unsettled statuses and clouds on many titles, since the statutory presumption could sometimes be overcome.

By its nature, prospective application of an overruling decision results in inconsistent treatment of litigants whose rights are determined at different points in time. But the alternative involves frustrating litigants who have relied on the law as it was formerly declared. By declaring the unacceptability of notice by publication where the defendant's name and address are known or ascertainable the Court has "thrown a nationwide cloud of uncertainty"45 upon a great number of concluded proceedings which involved such notice. Because of this great reliance on the previous law, and because of the doubtful ability of the states to limit Supreme Court decisions, it is regrettable that the Court itself did not limit the decision to prospective application. The circumstances were particularly advantageous since the Court's decision reflects not so much a substantive change in the law of due process as a declaration that methods of notice previously acceptable have diminished in effectiveness to a degree where they no longer satisfy the requirements of due process. The argument that prospective operation removes incentive to appeal would not apply if the Court were also to decide the case before it on the basis of

notice of condemnation of a building in a city. It is far less probable that he will have notice of partial condemnation of underdeveloped land in a rural area.

${ }^{23}$ E.g., Pflueger v. Hopple, 66 Idaho 152, 156 P.2d 316 (1945).

"Pennoyer v. Neff, 95 U.S. 714 (1878).

${ }^{\star}$ Walker v. City of Hutchinson, 352 U.S. 112, 127 (1956) (Burton, J., dissenting), quoted in note 29 supra. 
the new law. ${ }^{46}$ Nor would the argument that it is not the true function of the judiciary to set down law for the future ${ }^{47}$ seem to have any relevancy in this situation, assuming it has any validity at all, since the job of interpreting the due process clause by its nature belongs to the courts and cannot be an encroachment on the function of the legislature.

${ }^{48}$ This procedure was followed in Shioutakon v. District of Columbia, 236 F.2d 666, 670 (App. D.C., 1956) ; Durham v. United States, 214 F.2d 862, 874 (App. D.C., 1954) ; Steward v. United States, 214 F.2d 879, 882 (App. D.C., 1954); cf. Addison v. Holly Hill Co., 322 U.S. 607, 619-22 (1944).

${ }^{47}$ Consult Moschzisker, Stare Decisis In Courts Of Last Resort, 37 Harv. L. Rev. 409, 426-27 (1924).

\section{JUDGMENTS OF ACQUITTAL: THE RIGHT TO A NON-JURY TRIAL}

\section{I}

Judgments of acquittal ${ }^{1}$ in criminal cases have a relatively short history. Not until $1850,{ }^{2}$ and in some instances even later, ${ }^{3}$ was the notion that the jury is properly the trier of issues of law as well as fact finally discarded and the civil practice of demurrer to the evidence carried over into the criminal courts. ${ }^{4}$ Today, by reason of general recognition of the acquittal procedure, ${ }^{5}$ controversy has shifted to the circumstances which require the trial judge to take a case from the jury. Surprisingly enough, at least three distinct tests have been developed. Deserving of particular interest is the position of the Court of Appeals for the Second Circuit, recently reaffirmed in United States v. Masiello, ${ }^{6}$ that "the standard of evidence necessary to send a case to the jury is the same in both civil and criminal cases. . .."

${ }^{1}$ The term directed verdict has been replaced in federal criminal cases by the phrase "motion for judgment of acquittal." 62 Stat. 869 (1948), 18 U.S.C.A. $\$ 29$ (a) (1951). This change in nomenclature did not modify the nature of the motion or enlarge the scope of the matters to be considered in ruling on it, Note to 18 U.S.C.A. $\$ 29$ (a) (1951), and will be followed herein.

${ }^{2}$ Parks v. Ross, 11 How. (U.S.) 361 (1850) (trial judge may give the jury an imperative instruction to find for the accused); see United States v. Battiste, 24 Fed.Cas. 1042 (C.C. Mass., 1835).

${ }^{3}$ Connecticut, for example, as late as 1894 had a statute which forbade the trial judge from directing the return of any particular verdict. See State v. Fetterer, 65 Conn. 287, 32 Atl. 394 (1894).

'Consult Blume, Origin and Development of the Directed Verdict, 48 Mich. L. Rev. 555 (1950), for a detailed historical analysis.

${ }^{5}$ Only Louisiana and North Dakota do not permit directed verdicts in criminal cases. State v. Broussard, 217 La. 90, 46 So.2d 48 (1950) ; State v. Pusch, 77 N.D. 860, 46 N.W.2d 508 (1950).

235 F.2d 279 (C.A. 2d, 1956) (alternative holding by divided court), cert. denied 352 U.S. 882 (1956).

${ }^{7}$ United States v. Feinberg, 140 F.2d 592, 594 (C.A. 2d, 1944). 